\title{
Pandemic India: Coronavirus and the Uses of History
}

\section{DAVID ARNOLD}

The onset of the COVID-19 pandemic has produced two different narratives in India. One, here described as "historical," looks back to the pandemics of the colonial pastbubonic plague from 1896, influenza in 1918-19_as a source of comparisons, lessons, and dire warnings for the present. This narrative envisages the reenactment of past scenes, including flight from the cities, victimization of the poor, and the questioning of state authority. The other narrative, here called "insurgent," questions the value of historical analogies, doubts that history ever substantially repeats itself, and stresses the specificity of postcolonial Indian politics and health. While recognizing the validity of both narratives, the author urges caution in employing colonial history to critique contemporary events and, while recognizing the 1890s plague as a watershed moment, questions whether even the most devastating pandemics (such as 1918's influenza) necessarily result in profound social, political, and health care changes.

Keywords: India, coronavirus, pandemics, history, plague, influenza

$\mathrm{T}$

THERE ARE TWO NARRATIVES at large in India's COVID-19 story. One we might label "historical," the other "insurgent." Taking the historical first, the lessons and legacies of the past hang heavily over recent South Asian experience. COVID-19 might be a "novel" coronavirus to the epidemiologist, but to the historian, there is much about the behavior of the disease and the sociopolitical responses it has elicited that appears decidedly lacking in novelty. The events of early 2020 have so compellingly reminded commentators of the long sequence of pandemics that issued from or impacted the Subcontinent over the previous two hundred years - cholera from 1817, bubonic plague from 1896, influenza in 1918 - that it has become commonplace, almost facile, to say that history is repeating itself. ${ }^{1}$ As if to give credence to the idea of a recurring history, epidemiologists have long predicted that, a century on from the "Spanish flu" of 191819 (in which a quarter, perhaps a third, of the 40 to 50 million deaths worldwide occurred in India), a new pandemic, probably of influenza, was almost inevitable. India, with its billion-plus people, high population densities, widespread malnutrition and poverty,

David Arnold (d.arnold@warwick.ac.uk) is Professor Emeritus in the Department of History, University of Warwick, United Kingdom, and the author of Colonizing the Body: State Medicine and Epidemic Disease in Nineteenth-Century India (1993) and Burning the Dead: Hindu Nationhood and the Global Construction of Indian Tradition (forthcoming).

${ }^{1}$ Anirban Chanda and Sahil Bansal, "The 1896 Bombay Plague: Lessons in What Not to Do," Outlook, April 9, 2020, https:/www.outlookindia.com/website/story/opinioncolonial-\%20experiences\%20from-the-bombay-plague-of-1896-no-lessons-learned/350389 (accessed April 10, 2020); Ramachandra Guha, "Repeating the Past," Telegraph (Kolkata), April 25, 2020, https://www.telegraphindia.com/opinion/coronavirus-india-the-gover\%E2\%80\%A6ious-minoritiesduring-covid-19lockdown-and-pandemic/cid/1767769 (accessed April 25, 2020). 
millions of migrant workers, and defective public health infrastructure, was bound to suffer most. By the template of 1918, millions of Indians would die. ${ }^{2}$

Although pandemics and epidemics are commonly conflated, as if the former were merely the latter writ globally large, COVID-19 reminds us how different in their social dynamics and political reverberations one is from the other. Governments and health services try to manage their own epidemics; pandemics have long been global business. Held responsible for successive "waves" of disease-cholera, smallpox, dengue, plagueadvancing overland toward Europe or entering the maritime circuits of the Indian Ocean, nineteenth-century India unwittingly helped fashion the modern concept of a pandemic, a concept that ran counter to widely held beliefs about the local origins of disease and varying susceptibility between races. Globalization, with India as one of its principal nodes, further shaped the modern pandemic. Steamships and railroads, burgeoning international trade, and the movement of migrant labor (from and across South Asia) increased the speed and extended the reach of epidemic transmission and, aided by newspapers and telegraphs, fostered a global sense of vulnerability and alarm. While the progress of the cholera pandemic of 1817-23 was relatively slow, taking years to penetrate Western Europe and North America, by the late nineteenth and early twentieth century, it took only months for plague and weeks for influenza to traverse the globe.

In each of these pandemics, India played a different role. In the cholera pandemic of the nineteenth century, India was (as critics of British rule seldom tired of arguing) the originator, incubator, and disseminator. With bubonic plague, India was the recipient of a disease coming (as now with COVID-19) westward out of China, but one that was especially feared lest India's ports passed on this latter-day Black Death to the Middle East and Europe. Ultimately, more than 90 percent of plague deaths worldwide occurred in India. With influenza in 1918, India was again a recipient, this time of a pandemic marching from west to east, from the war zones of Europe and the Middle East. Plague rumbled on for years; influenza did its killing in months. In this last great pandemic, India, despite suffering at least 12 million deaths, received scant international attention, its mortality overshadowed by war and the more widely publicized ravages of the disease in the West. With cholera and plague, India was the main story; with influenza, it was a sideshow.

Ever since the cholera of the nineteenth century, pandemics have triggered a global blame game, a naming and shaming, that often simulates old rivalries. How has Britain done in the pandemic league compared with Germany, and India with Pakistan? As cholera so evidently erupted out of India, other empires and nations blamed the British for these deadly and repeated explosions and for the apparent failure of the colonial regime to stop the pandemics at their source, implicating Hindu bathing festivals, or, critiquing the hajj, along the lines of westward transmission from India to Europe's eastern approaches. International naming and shaming no longer operates-officially —through such stigmatizing geographic designations as "Asiatic cholera" or "Hong Kong flu," and yet the effect on the global pandemic imagination remains much the same.

${ }^{2}$ Lalit Kant and Randeep Guleria, "Pandemic Flu, 1918: After Hundred Years, India Is as Vulnerable," Indian Journal of Medical Research 147, no. 3 (2018): 221-24; Christopher Murray et al., "Estimation of Potential Global Pandemic Influenza Mortality on the Basis of Vital Registry Data from the 1918-20 Pandemic," The Lancet 368, no. 9554 (2006-07): 2211-18. 
Through international sanitary conferences (the ancestors of today's World Health Organization) from 1866 onward, attempts were made to bring British India to heel, to shame its sanitary shortcomings, and to establish a system of inspection and quarantine stations to protect Europe "against the importation of exotic diseases from the East."3 Despite British objections to restrictions on free trade and the unfettered movement of people, some measures stuck, though the transparent concern was to protect Europe and North America from pandemic Asia, rather than to rid India its epidemic afflictions. Still more strikingly, the outbreak of bubonic plague in Bombay (Mumbai) in 1896 prompted fresh demands for sanitary intervention, backed at the Venice conference of February and March 1897 by a threatened embargo on India's maritime trade if the British did not react immediately. The upshot was the Epidemic Diseases Act of 1897, a piece of draconian sanitary legislation that has now been resurrected, 123 years later, by the present government of India to tackle a comparable crisis of global magnitude. ${ }^{4}$

It is not hard to imagine the chaotic and distressing scenes of 1896-97-the mass flight of the laboring poor as the panic caused both by the disease and by anti-plague operations took hold, the hosing down of tenements and the burning of hovels, the enforced hospitalization of suspects snatched from homes and streets, the brutish body inspections at railroad stations, the riots and attacks on doctors and ambulance attendants, the curtailed cremations and lime-splattered corpses, the mounting daily tally of the dead-transposed to India of the recent past. ${ }^{5}$ Then, as now, the middle classes could save themselves by self-isolating (in part, in the 1890s, by establishing "caste hospitals"), insulated by the privileged distancing of caste, class, and gated communities, while for the poor, self-isolation was (and is) a fantasy. ${ }^{6}$ Then, as now, the slum dwellers and the migrant poor were doubly victimized-by disease and by loss of livelihood.

For all the attention lavished on India's middle classes in recent times, as a result of the coronavirus and the state measures in reaction to it, the awkward presence of the masses has again asserted itself, as it did with plague and influenza, only now elevated to a new domestic prominence and global visibility. COVID-19 has directed renewed attention to India's armies of informal labor, the migrant poor who move, often seasonally, from the countryside to the cities in search of work, and who in troubled times like these seek to return to villages where they feel more secure and have greater access to food and

\footnotetext{
${ }^{3}$ Norman Howard-Jones, The Scientific Background of the International Sanitary Conferences, 1851-1938 (Geneva: World Health Organization, 1975), 81.

${ }^{4}$ David Arnold, Colonizing the Body: State Medicine and Epidemic Disease in Nineteenth-Century India (Berkeley: University of California Press, 1993); Tarangini Sriraman, "Plague Passport to Detention: Epidemic Act Was a Medical Surveillance Tool in British India," ThePrint, March 22, 2020, https://theprint.in/opinion/plague-passport-to-detention-epidemic-act-was-a-medical-surveilance-tool-inbritish-india/385121 (accessed March 24, 2020).

${ }^{5}$ Prerna Agarwal, "The Government Will Come to Its Senses," India Forum, May 1, 2020, https:// www.theindiaforum.in/article/government-will-come-its-senses (accessed May 2, 2020); M. E. Couchman, Account of the Plague Administration in the Bombay Presidency, from September 1896 to May 1897 (Bombay: Government Central Press, 1897).

${ }^{6}$ Srividya Balasubramanian, "Social Distancing as Class Experience: A Field Report from India," ReCentGlobe-Blog, April 14, 2020, https://www.recentglobe.unileipzig.de/zentrum/detailansicht/ artikel/blog-7-social-distancing-as-class-experience-afield-report-from-india-2020-04-14/ (accessed April 19, 2020).
} 
shelter $^{7}$. Much as they did in March and April 2020 from Delhi, Mumbai, Surat, and Hyderabad, between October 1896 and the end of February 1897, an estimated 380,000 people fled Bombay, then a city of 850,000 .

COVID-19 illuminates a half-forgotten truth that for many of these people, the city remains an alien space: as one participant in a comparable exodus from Dhaka in Bangladesh put it, "the city is not ours." ficially appear to be, such a pandemic (or the measures that panicked governments impose) exposes the enormous economic and social gulf between the two. Yet while the city might be alien space to many migrant workers, as in the plague past, the authorities try to contain infection within the cities, where it might be amenable to surveillance (doctors, drones, apps), fearing that once the contagion moves into the villages it becomes far more difficult to manage and detect. The impulse to protect society and the economy by corralling and disinfecting the poor remains as vital a principle of state action now as when an earlier generation was herded into plague camps and screened through inspection depots in the 1890s and 1900s. ${ }^{9}$

Historians can only visualize the plague scenes of 1896-97 through the partisan lens of colonial photography or read about them in old newspapers and municipal reports. Now, we can witness them reenacted before our eyes through mobile phones and video cameras, on prime-time television and social media, hourly exposed to national debate and global scrutiny, and with no retrospective certainty as to what the outcome might be. The desperate flight from the cities in March and April 2020 put some observers in mind of Partition's mass migrations. ${ }^{10}$ In India there is an older tradition of investigative journalism that goes back at least to William Digby and the "famine campaign" of the 1870s, but now the poor have a name, a face, a voice: they speak with anger and frustration to the inquiring audio-journalist. ${ }^{11}$ They - and the calamity they inhabit-exist in real time. Does greater immediacy engender greater empathy? Some historians claim that epidemics can bring people together across entrenched social divides: there is an upwelling of compassion, a common sense of danger, a shared notion of who or what the enemy might be. ${ }^{12}$ More likely, the current trend in India suggests an epidemic, still more a pandemic, forces social divisions more starkly into the open, transforming fissures into fault lines. There is a subaltern politics still.

${ }^{7}$ Ranabir Samaddar, ed., Borders of an Epidemic: COVID-19 and Migrant Workers (Kolkata: Mahanirban Calcutta Research Group, 2020).

${ }^{8}$ Mohammad Tareq Hasan, "Homecoming from the City: Covid-19 and Dhaka," Medical Anthropology at UCL, April 15, 2020, https://medanthucl.com/2020/04/15/homecoming-from-the-citycovid-19-dhaka/ (accessed April 17, 2020).

${ }^{9}$ Pushpa Arabindoo, "Pandemic Cities: Between Mimicry and Trickery," City \& Society 32, no. 1 (2020), https://doi.org/10.1111/ciso.12263.

${ }^{10}$ Samata Biswas, "Bringing the Border Home: Indian Partition 2020," in Borders of an Epidemic: COVID-19 and Migrant Workers, ed. Ranabir Samaddar (Kolkata: Mahanirban Calcutta Research Group, 2020), 104-14.

${ }^{11}$ William Digby, The Famine Campaign in Southern India, 1876-78, 2 vols. (London: Longman, Green, \& Co., 1878).

${ }^{12}$ Samuel K. Cohn Jr., Epidemics: Hate and Compassion from the Plague of Athens to AIDS (Oxford: Oxford University Press, 2018). 
In the 1890s, British India was shamed by having a succession of foreign experts visit its shores to investigate plague (and cholera before it), though the faltering reputation of colonial medical science was then partly redeemed by the anti-plague serum developed by the Russian émigré and Pasteurian bacteriologist Waldemar Haffkine in Bombay and by the intensive epidemiological research that followed. India's plague gave lessons to the world - and a crib sheet for the present. In the earlier pandemics, troops played a prominent role, as they and their camp followers tramped across India, trailing cholera in their wake or, in the time of influenza, with returning soldiers and intensive troop movements across a half-starved, war-wracked India. During the plague episode, soldiers were more in evidence as enforcers of unpopular sanitary regulations than as disseminators of disease. So far, in this there are no obvious parallels with COVID-19. The modern armies of the infected are returning tourists or "stranded" migrants. And yet, now as then, the language of martial resolution and military maneuvers persists. Prime Minister Narendra Modi declared in an address to the nation that it was necessary to wage war against coronavirus. The struggle was a life-and-death battle, one that India needed to win. ${ }^{13}$

Who in a time of coronavirus has sovereignty over the body? Who claims - and exercises - the right to minister to its ills? Certainly, the Indian state claims a primary entitlement, but that state is itself divided between the central government and the states of the Indian Union, which (like the provinces of the Raj) have shown a lively determination to exercise their own initiative. Modi may have ordered an India-wide lockdown (with only four hours' notice on March 24), but states have chosen to extend or to interpret it after their own fashion, often with strikingly different results. ${ }^{14}$ As in earlier pandemics, vernacular alternatives to biomedicine abound. To the consternation of health care professionals, alternative therapeutics are touted as prophylactics or cures; there is nothing peculiarly South Asian about that. Plague and influenza-and the woeful deficiencies in colonial public health they exposed-were a great stimulus to the revival of India's indigenous medical systems and to homeopathy. Today's proffered remedies include cow urine and dung; elsewhere COVID-19 has been rationalized as a righteous punishment for those who irreligiously eat meat. ${ }^{15}$ Pandemics are opportunistic world travelers, but, chameleon-like, they also take on the color and complexion of the societies they come to inhabit. Once there were goddesses who brought or constrained smallpox, cholera, and plague, deities demanding exceptional reverence and devotion in epidemic times. In India now, under the aegis of the ruling Bharatiya Janata Party (BJP) and the ascendency of the Hindu right, the protecting, propitiatory deity might be construed as Hinduism itself.

13“Coronavirus: India’s PM Modi Seeks 'Forgiveness' over Lockdown,” BBC News, March 29, 2020, accessed July 1, 2020, https://www.bbc.com/news/world-asia-india-52081396 (accessed July 1,2020).

${ }^{14}$ P. K. Yasser Arafath, "Success of the Kerala Model," Telegraph (Kolkata), April 24, 2020, https:// www.telegraphindia.com/opinion/cornonavirus-kerala-success-wit...-byits-high-level-of-literacyand-secular-sensibilities/cid/1767508 (accessed April 25, 2020).

${ }^{15}$ Kaveree Bamzai, "Between Sanitiser and Gaumutra for Covid-19, Many in Modi’s India Have Made Historical Choice,” ThePrint, March 21, 2020, https://theprint.in/opinion/gaumutra-forcovid-19-modis-india-made-historical-choice/384819/ (accessed March 24, 2020); “Assam BJP MLA Suman Haripriya: Cow Dung, Urine May Cure Coronavirus," Times of India, March 3, 2020. 
But history does not simply repeat itself, its lessons rewashed and hung out to dry. As Hegel might have said, every pandemic is basically the same; every pandemic is profoundly different. This is 2020, not 1896 or 1918, and it is possible to conceive an insurgent narrative, a tale from the Global South, that runs counter to the historical trajectory culled from a colonial past or reimagined via an epidemiological orthodoxy still rooted in the West. ${ }^{16}$

As yet, as of late May 2020, deaths from COVID-19 have not repeated earlier pandemic patterns. During the tsunami-like onset of plague, and especially in influenza's deadly second wave, the contagion sped through India's urban communities and rapidly invested small towns and villages. In one day alone-October 6, 1918-there were 768 influenza deaths in Bombay. The largely rural Central Provinces (Madhya Pradesh) lost one-tenth of its population in a matter of weeks. Conversely, in the three months from January 30, 2020, when the first COVID-19 case was recorded in India, there were just over a thousand acknowledged deaths $(1,154)$ from the disease, with a further 537 across the rest of South Asia. In this period, India recorded fewer COVID-19 deaths than Ireland. More ominously, though, by May 10, India's tally had passed 2,000 and, as India was easing lockdown restrictions, reached more than 5,000 deaths and over 180,000 cases by early June. There have been cases of COVID-19and deaths - in Mumbai's densely populated Dharavi slum, but as yet, nothing on the scale of sickness and mortality so inescapably evident among the urban poor when plague and influenza took hold. However, until June, COVID-19 cases and deaths were largely concentrated in a few cities and states, principally Mumbai and Maharashtra in western India; but with rapidly expanding numbers of cases and deaths, the India-wide potential of the pandemic becomes apparent.

Perhaps-apocalypse deferred - it is simply too soon to know how the pandemic will affect India. But several possible explanations have been offered for the relatively low mortality thus far: some strains of COVID-19 might be more lethal than others; heat might be inimical to the spread of the virus, and a clearer picture will emerge with the monsoon (the flu season in northern India); India's age profile is very different from that of Western countries, where care home residents and those over seventy have proved most vulnerable; misdiagnosis and underreporting may be rife in a country where 80 percent of deaths occur at home, not in hospital; testing and tracing are wholly inadequate. ${ }^{17}$ Conceivably, despite the chaotic scenes that marked its abrupt beginning, India's lockdown may have worked and slowed the rate of infection. And, if we value statistics, we might set the thousand-plus deaths from COVID-19 during the first three months in India alongside the 150,000 fatalities that occur annually on the country's roads, the 10 million deaths from all causes every year, or the 200,000 farmer suicides since 1997. Events elsewhere have given this rogue virus a prominence thatin terms of mortality alone-it might not otherwise have commanded.

\footnotetext{
${ }^{16}$ Sheetal Chhabria, "Manufacturing Epidemics: Pathogens, Poverty, and Public Health Crises in India," India Forum, June 5, 2020, https://www.theindiaforum.in/article/manufacturing-epidemics (accessed June 6, 2020).

${ }^{17}$ Arup Malani, Arpit Gupta, and Reuben Abraham, "Why Does India Have So Few Covid-19 Cases and Deaths?," Quartz India, April 16, 2020, https:/qz.com/india/1839018/why-does-india-have-sofew-coronavirus-covid-19-caseanddeaths/ (accessed July 1, 2020).
} 
But an insurgent narrative needs to be about more than explaining why the pandemic has or has not happened as might have been expected so far. It is also about how we reorient our historical vision and epidemiological understanding. In the late 1890s and early 1900 s, at the height of the colonial era, India was beset by famine and besieged by serial epidemics of cholera and malaria; famine and food shortages were rife again in 1918-19. India is not in that extremely vulnerable position today, even though poverty and malnutrition remain widespread. One effect of the lockdown may be to push millions of Indians once more to the brink of starvation or render them more susceptible than they would otherwise have been to other infections. In the 1890s and 1900s, India's pharmacological industry was in its infancy; Bombay's Haffkine Institute was one of the first institutions to manufacture an anti-plague serum on a large scale. Now India is one of the world's leading producers of generic drugs and annually exports billions of doses of vaccines to countries worldwide. India's manufacture of the antimalarial hydroxychloroquine even had the president of the United States threatening India with "retaliation" unless it continued to allow the export of the drug as a (unproven) prophylactic for coronavirus. If there is to be an effective vaccine against COVID-19, it is likely that it will be mass-produced in India.

The influenza pandemic was a hundred years ago, when India’s medical establishment was overstretched and depleted by the demands of war and constrained by narrow colonial healthcare priorities. Since then India has ridden out a host of lesser epidemics, from cholera to chikungunya, from the "Asian flu" of 1957 to the swine flu of 2009 , without mortality on anything like 1918 's apocalyptic scale. ${ }^{18}$ Western countries may have begun to think themselves relatively immune to pandemics: India has not had that luxury. Further, it has played a major role in the eradication of smallpox and the containment of polio, and, with the number of cases and deaths falling, it has hopes of eliminating malaria by 2030. India's health system may be defective, overstretched, and underresourced, but have those of the United States and Britain fared any better? When it comes to handling a modern pandemic, the West might learn something from China, Taiwan, South Korea, Singapore, and (it may yet be) India. At the least, the pandemic has taught India once more to be self-reliant - to look to its genius for innovation and improvisation - rather than to expect substantial help from the West. And yet this narrative is still an "insurgent" one, for the fragility of India's already faltering economy, the persistence of extreme social inequality, and the flawed capacity to deliver health care to those who need it most, make this an aspiration and not yet an assured and definitive statement. And, as elsewhere, the Indian government has to battle with the competing demands of protecting public health and reviving the postlockdown economy.

In many countries, COVID-19 unleashed a wave of Sinophobia: in India it erupted into Islamophobia. Following close on unrest over the Citizenship Amendment Act, which appeared to discriminate against Muslims, an outbreak of the disease at a gathering of the Islamic organization Tablighi Jamaat in Delhi in March, where a cleric from Indonesia may have introduced the infection, led to wild claims about this being the source of

${ }^{18}$ I. G. K. Menon, "The 1957 Pandemic of Influenza in India," Bulletin of the World Health Organization 20, no. 2-3 (1959): 199-224. 
thousands of cases (and dozens of deaths) across India. There have been wild rumors-of a nature and on a scale perhaps not seen since the plague days in 1896-97_of Muslims deliberately infecting food and water to spread the virus. They have been collectively accused of being "coronavirus terrorists," plotting a "Taliban crime," and launching a "corona jihad." In some towns and villages, Muslims have been ostracized, beaten up, and abused, with signs put up to deny them entry. ${ }^{19}$ Secure in the landslide majority won by the BJP in 2019's elections, the Modi government has been slow to counter or condemn this tide of vilification and hatred.

But if there are echoes here of the rumors and violence of the $1890 \mathrm{~s}$, we should remind ourselves that then the target of such acts and suspicions was a colonial regime whose often arbitrary conduct, and whose apparent unconcern for the values and wellbeing of the people, provoked a backlash across classes and communities. The intensity of that reaction forced the colonial authorities to backtrack, moderate the more extreme measures adopted under the Epidemic Diseases Act, and seek a fresh rapport with the Indian middle classes. In attempting this conciliatory maneuver, colonial officialdom was only partly successful, and India's plague years spawned a new politicization of both classes and masses. Very different is the situation today, when the pandemic is seized upon to mobilize majoritarian hostility not to an unpopular colonial regime but to a perceived "enemy" within. Nor is there any obvious parallel in colonial surveillance and censorship to what a coronavirus-tracing app might do to trespass on personal freedom and augment state power. Perhaps if the Modi government's resurrection of the 1897 act fails to check the spread of coronavirus, if the economy contracts, and India becomes, as epidemiologists have predicted, the pandemic's worst-case scenario, then conceivably a reaction will set in and the regime itself will become, like the British before it, a target of intense hostility. But the BJP-led government in Delhi has more ideological weapons and political tools at its effective command than the British had in the 1890s. It is better placed than ever they were either (if things go well) to claim a heroic victory and a vindication for the prime minister's resolute and decisive action, or (if they do not) to deflect criticism onto an internal, scapegoated, "other," or an external one, such as China, with whom India's relations have become increasing belligerent during the COVID-19 months.

COVID-19 poses challenging questions for the historian. What exactly, in these pandemic times, is the use of history? Or, indeed, of colonialism? In times of such uncertainty, we understandably seek a usable past, to comfort, guide, or reprimand the present. Nineteenth-century colonial sanitarians used cholera to show an India still sunk in its past, mired by outdated custom and ancient superstition. Today, colonialism becomes a stick with which to beat the regime in power. Perhaps, pandemics are simply too complex and fine-grained a phenomenon, too bound by specificities of time, place, and culture, to be used in so hasty a fashion.

\footnotetext{
${ }^{19}$ Apoorvanand, "How the Coronavirus Outbreak in India Was Blamed on Muslims," Al Jazeera, April 18, 2020, https://www.aljazeera.com/indepth/opinion/coronavirus-outbreak-india-blamedmuslims-200418143252362.html (accessed April 20, 2020); Hannah Ellis-Petersen and Shaik Azizur Rahman, "Coronavirus Conspiracy Theories Targeting Muslims Spread in India," Guardian, April 13, 2020, https://www.theguardian.com/world/2020/apr/13/coronavirus-conspiracy-theoriestargetingmuslims-spread-in-india (accessed April 14, 2020).
} 
In seeking to give due weight to the role of epidemics in history and to counter earlier neglect, historians have often argued that epidemics-still more pandemicswere game changers, that the demographic and economic loss they caused, the cultural shock and social trauma they occasioned, impelled profound and far-reaching change. The Black Death of the fourteenth century and the cholera pandemics of the nineteenth have been viewed in this way. But we should be wary of ascribing too much to pandemics. Certainly, as it affected India, the plague pandemic of the 1890s and 1900s produced significant practical and attitudinal changes in both government and the governed. But that could hardly be said of influenza in $1918-19 .{ }^{20}$ At least 12 million people died, and countless millions more fell sick. Because of the way in which the disease targeted those in the twenty to forty age range, the disease (and concurrent famine) left tens of thousands of widows and orphans in its wake.

And yet, the almost unimaginable death toll aside, it is doubtful that influenza changed very much. Neither colonialism nor capitalism collapsed; nor did the disease provoke-in India-much-needed health reform or greatly stimulate medical research. It did add weight to the protests that fueled the Rowlatt Satyagraha in 1919 and so helped propel Gandhi into all-India prominence, but the massacre at Jallianwala Bagh (with perhaps 500 people killed) that April did far more than influenza's 12 million fatalities to propel India into an age of mass nationalism and ardent anticolonialism. For all its mass mortality, influenza was little politicized or memorialized in India at the time and, in stark contrast to the bubonic plague (when colonial photography found much to commemorate), passed almost without visual record. COVID-19 already has outstripped the plague pandemic in its visual presence and its likely impact on individual and collective memory: who will not remember where they_or family members_-were when coronavirus happened? But will the skies over Delhi be clear again when the lockdown is over; will the waters of the Ganges remain unpolluted? It is too soon to say, but I doubt it.

\section{Acknowledgments}

The author thanks Shruti Kapila, Projit Bihari Mukharji, Robert Peckham, and the anonymous reviewers for their thoughts.

${ }^{20}$ David Arnold, "Death and the Modern Empire: The 1918-19 Influenza Epidemic in India," Transactions of the Royal Historical Society 29 (2019): 181-200. 